A N N A LE S

U N IVERSITATIS MARIAE C URIE-S KŁO D O W S A LUBLIN - POLONIA

VOL. XXX, 2

SECTIO J

2017

Uniwersytet Jana Kochanowskiego w Kielcach. Wydział Pedagogiczny i Artystyczny

\title{
LIDIA PAWELEC
}

lidiapawelec@op.pl

\section{Jakość przygotowania zawodowego nauczycieli $w$ świetle badań empirycznych}

The Quality of Vocational Training of Teachers in Empirical Research

\section{STRESZCZENIE}

W dzisiejszych czasach coraz trudniej znaleźć nauczyciela, który posiada kwalifikacje do nauczania tylko jednego przedmiotu. Wobec nauczycieli stawiane są bardzo wysokie wymagania, które niejednokrotnie okazują się trudne do spełnienia. W dużym stopniu przyczyniła się do tego stanu rzeczy rewolucja cywilizacyjna, ogromny przyrost informacji i niespotykane dotąd tempo przemian, które wzmocniły wartość wykształcenia na rynku pracy i sprawiły, że jego jakość stała się jednym z priorytetów współczesnej edukacji. Coraz częściej mamy do czynienia z wieloprzedmiotowością nauczycieli, która oznacza, że jeden nauczyciel posiada kompetencje do nauczania dwóch lub kilku przedmiotów. Często dodatkowe przedmioty są dość odległe od tego podstawowego.

Sytuacja taka w dużym stopniu podyktowana jest niestety względami ekonomicznymi. Szkoła preferuje posiadanie mniejszej liczby nauczycieli wielokierunkowych, którzy wykonują pracę kilkunastu osób, co w ogromnym stopniu zmniejsza koszty zatrudnienia. Jest to również korzystne z perspektywy samych nauczycieli, którym coraz trudniej utrzymać etat w szkołach. Zdobywanie kwalifikacji w dziedzinach, które się ze sobą nie pokrywają, jest obecnie w polskim systemie oświaty zjawiskiem powszechnym.

Celem przeprowadzonych badań było poznanie opinii nauczycieli z powiatu ostrowieckiego na temat jakości dokształcania z przedmiotów dodatkowych. Badania przeprowadzono wśród nauczycieli szkół podstawowych i gimnazjalnych powiatu ostrowieckiego. Zastosowano metodę sondażu diagnostycznego, w ramach której wykorzystano technikę ankietowania.

Słowa kluczowe: wieloprzedmiotowość; jakość kształcenia; studia podyplomowe 


\section{WPROWADZENIE}

Zawód nauczyciela jest jednym z najbardziej licznych w Europie. Ponad 6 mln osób pracuje w krajach europejskich jako nauczyciele szkół podstawowych i średnich, a na jednego nauczyciela przypada średnio 12-14 uczniów (Pruch 2006, s. 294). Przedstawiciele tej profesji są świadomi służby społecznej, powołania i stania na straży określonych systemów normatywnych. Wymaga się od nich bowiem nie tylko odpowiednich kwalifikacji zawodowych, ale też określonych cech osobowości, które są źródłem odpowiednich postaw i zachowań moralnych (Kutrowska 2008, s. 49). Profesjonalne i pełne przygotowanie do pracy w tym zawodzie, kompatybilne z nieustannie zmieniającymi się warunkami społeczno-gospodarczymi, stanowi istotny składnik kompetencji nauczyciela. Ów profesjonalizm rozumiany jest zwykle jako pogłębiona wiedza specjalistyczna i szerokie umiejętności metodyczne. Oczywiście ważne są także postawy, poglądy, zainteresowania, myślenie twórcze, stosunek do świata wartości, kultury, społeczeństwa, drugiego człowieka, samego siebie itd. Współczesny nauczyciel musi rozumieć kierunek zachodzących przemian i w nich uczestniczyć. Tylko w ten sposób może wspierać uczniów w obszarze zdobywania przez nich kompetencji społecznych, które przyczyniają się do ich rozwoju społecznego, umożliwiającego twórczą adaptację (Rutkowiak 1995, s. 299).

\section{SYSTEM KSZTAŁCENIA}

Osoba, która chce wykonywać w Polsce zawód nauczyciela, musi posiadać odpowiednie kwalifikacje określone w przepisach prawnych. Reguluje to przede wszystkim ustawa - Prawo o szkolnictwie wyższym oraz ustawa o systemie oświaty i wydawane na ich podstawie rozporządzenia. Zdobywanie kwalifikacji zawodowych przez nauczycieli odbywa się kilkoma drogami - najczęściej w systemie szkolnictwa wyższego, na studiach: zawodowych, jednolitych magisterskich, uzupełniających magisterskich lub studiach podyplomowych. Nauczyciele przedszkoli, szkół podstawowych i gimnazjów kształcą się w ramach systemu oświaty w kolegiach nauczycielskich i nauczycielskich kolegiach języków obcych. W ramach studiowania danego kierunku student może wybrać specjalność nauczycielską i zdobyć podczas studiów kwalifikacje uprawniające go do pracy w szkole. Istnieje także możliwość uzupełnienia przygotowania pedagogicznego na studiach podyplomowych lub kursach kwalifikacyjnych (Federowicz, Sitek [red.] 2011, s. 190).

Przygotowanie nauczyciela do zawodu obejmuje następujące elementy: kształcenie kierunkowe (dla poszczególnych kierunków studiów, obejmuje nabycie wiedzy i umiejętności merytorycznych), kształcenie nauczycielskie (przy- 
gotowanie z psychologii, pedagogiki, dydaktyki przedmiotowej, przygotowanie do pracy wychowawczej, opiekuńczej, dydaktycznej), praktyki pedagogiczne (poznanie organizacji i funkcjonowania szkół i placówek, nabywanie i rozwijanie umiejętności zawodowych), kształcenie w zakresie technologii informacyjnej, kształcenie w zakresie języka obcego (Federowicz, Sitek [red.] 2011, s. 190).

Przygotowanie kierunkowe dotyczy nauczanego przez nauczyciela w szkole przedmiotu lub dziedziny wiedzy i obejmuje zakres wiedzy z danej dziedziny, grupy dziedzin czy przedmiotów pokrewnych. Przygotowanie pedagogiczne odnosi się natomiast do przygotowania psychologiczno-pedagogicznego i metodycznego, które warunkują pełne przygotowanie nauczyciela do podjęcia pracy z dziećmi i młodzieżą. Zgodnie z obowiązującymi w naszym kraju przepisami przygotowanie pedagogiczne oznacza nabycie wiedzy i umiejętności z psychologii, pedagogiki i dydaktyki szczegółowej, nauczanych w powiązaniu z kierunkiem (specjalnością) kształcenia i praktyką pedagogiczną w wymiarze nie mniejszym niż 270 godzin, oraz odbycie praktyk pedagogicznych w wymiarze nie mniejszym niż 150 godzin (ocenionych pozytywnie). Potwierdzeniem posiadania przygotowania pedagogicznego jest dyplom lub inny dokument wydany przez szkołę wyższą, dyplom ukończenia zakładu kształcenia nauczycieli i świadectwo ukończenia pedagogicznego kursu kwalifikacyjnego. W większości krajów na świecie (również w Polsce) nauczyciel bez względu na typ szkoły, przedmiot czy szczebel kształcenia musi posiadać wykształcenie wyższe. Według obowiązującej w krajach Unii Europejskiej Deklaracji Bolońskiej obowiązuje dwustopniowa struktura studiów wyższych. Podzielone są one zatem na dwa etapy: studia zawodowe (licencjackie/inżynierskie) i magisterskie (Podoska-Filipowicz).

\section{ZNAK CZASU - WIELOSTRONNOŚĆ}

Jeszcze kilkanaście lat temu każdy nauczyciel uczył jednego przedmiotu i był w jego zakresie specjalistą. Przygotowywały go do niego pięcioletnie studia magisterskie i odpowiednie przygotowanie pedagogiczne. Obecnie sytuacja diametralnie zmieniła się i coraz trudniej znaleźć nauczyciela, który posiada kwalifikacje do nauczania tylko jednego przedmiotu. Odważę się zaryzykować stwierdzenie, że takich nauczycieli obecnie już nie ma, a ci, którzy byli, odeszli już na emeryturę. Wobec nauczycieli stawiane są bardzo wysokie wymagania, które niejednokrotnie okazują się trudne do spełnienia. W dużym stopniu przyczyniła się do tego stanu rzeczy rewolucja cywilizacyjna, ogromny przyrost informacji i niespotykane dotąd tempo przemian, które wzmocniły wartość wykształcenia na rynku pracy i sprawiły, że jego jakość stała się jednym z priorytetów współczesnej edukacji. W takich realiach co chwilę ożywają dyskusje na temat nowego modelu oświaty i stanu przygotowania szkoły do zadań wynikających z rzeczywistości XXI w. 
Największym problemem staje się jakość kształcenia nauczycieli, którzy potrafią sprostać wymogom obecnego świata i przygotować ucznia do zmian, reorientacji zawodowej i samokształcenia, rozwijać jego refleksyjność, giętkość myślenia i zdolności twórcze, kształcić go do wolności wyborów i decyzji, pokoju, tolerancji, demokracji, współpracy i współdziałania (Kulka 2008, s. 23-24).

Rzeczywistość edukacyjna i społeczna wymaga od nauczycieli bardzo dużo, ale nie zawsze umożliwia im zdobycie pożądanych kompetencji w toku oferowanego kształcenia. Współczesny nauczyciel musi być wielowymiarowy i wielostronny. Wielostronne nauczanie oznacza kształtowanie czterech postaw: recepcyjnej, badawczej, uczuciowej i operacyjnej. Realizacja teorii wielostronności w kształceniu nauczycieli powinna wyrażać się w kształtowaniu aktywności poznawczej, emocjonalnej i praktycznej (Kuźma 2001, s. 271).

Owa wielostronność wyraża się obecnie m.in. przez wieloprzedmiotowość nauczycieli, która oznacza, że jeden nauczyciel posiada kompetencję do nauczania dwóch lub kilku przedmiotów. Często te dodatkowe przedmioty są dość odległe od podstawowego. Sytuacja taka w dużym stopniu podyktowana jest niestety względami ekonomicznymi. Szkoła preferuje posiadanie mniejszej liczby nauczycieli wielokierunkowych, którzy wykonują pracę kilkunastu osób. Oczywiście w ogromnym stopniu zmniejsza to koszty zatrudnienia. Jeśli jeden nauczyciel może uczyć 3 lub 4 przedmiotów, nie trzeba zatrudniać 3 lub 4 dodatkowych osób. Jest to również korzystne z perspektywy samych nauczycieli, którym coraz trudniej utrzymać etat w szkołach. Dzieci z roku na rok jest coraz mniej. Wskutek tego potrzeba także coraz mniej nauczycieli, ponieważ jest coraz mniej godzin. Co roku jednak mury uczelni opuszczają rzesze studentów z wykształceniem pedagogicznym. Jeśli nauczyciel nie chce biegać między kilkoma placówkami każdego dnia (a tak to często wygląda), musi zdobywać kwalifikacje do nauczania innych, niż swój „macierzysty”, przedmiotów. W efekcie zdarza się, że nauczyciel matematyki uczy też plastyki, a polonista - geografii. Zdobywanie kwalifikacji w dziedzinach, które się ze sobą nie pokrywają, jest obecnie w polskim systemie oświaty zjawiskiem powszechnym.

W roku szkolnym 2014/2015 w polskich szkołach i placówkach oświatowo-wychowawczych zatrudnionych było ogółem 670461 nauczycieli, w tym ponad 546 tys. w pełnym wymiarze godzin i ponad 124 tys. w niepełnym. Tab. 1 prezentuje poziom wykształcenia polskich nauczycieli z uwzględnieniem podziału na województwa.

Najliczniejszą grupę w roku szkolnym 2014/2015 stanowili nauczyciele z wykształceniem wyższym (97,53\%). Wykształcenie na poziomie Kolegium Nauczycielskiego (KN) i Nauczycielskiego Kolegium Języków Obcych (NKJO) miało natomiast $0,27 \%$, na poziomie Studium Nauczycielskiego (SN), Studium Pedagogicznego, Studium Technicznego (PST) i Studium Wychowania Przedszkolnego (SWP) - 0,65\%, a wykształcenie średnie - 0,50\% (Rachubka 2015, s. 19). 
Tab. 1. Liczba nauczycieli w Polsce zatrudnionych w roku szkolnym 2014/2015

\begin{tabular}{|c|l|c|c|c|}
\hline Lp. & \multicolumn{1}{|c|}{ Województwo } & $\begin{array}{c}\text { Liczba } \\
\text { nauczycieli } \\
\text { ogółem }\end{array}$ & $\begin{array}{c}\text { Liczba zatrudnionych } \\
\text { w pełnym } \\
\text { wymiarze godzin }\end{array}$ & $\begin{array}{c}\text { Liczba zatrudnionych } \\
\text { w niepełnym } \\
\text { wymiarze godzin }\end{array}$ \\
\hline 1. & Dolnośląskie & 46335 & 37333 & 9002 \\
\hline 2. & Kujawsko-pomorskie & 35853 & 30473 & 5380 \\
\hline 3. & Lubelskie & 39907 & 31031 & 8876 \\
\hline 4. & Lubuskie & 17095 & 14556 & 2539 \\
\hline 5. & Lódzkie & 41304 & 34009 & 7295 \\
\hline 6. & Małopolskie & 61536 & 48602 & 12934 \\
\hline 7. & Mazowieckie & 99020 & 80205 & 18815 \\
\hline 8. & Opolskie & 16639 & 13675 & 864 \\
\hline 9. & Podkarpackie & 38786 & 30585 & 4240 \\
\hline 10. & Podlaskie & 21066 & 16826 & 6705 \\
\hline 11. & Pomorskie & 41373 & 34668 & 13939 \\
\hline 12. & Śląskie & 75852 & 61913 & 4944 \\
\hline 13. & Świętokrzyskie & 21490 & 16546 & 3865 \\
\hline 14. & Warmińsko-mazurskie & 25039 & 21174 & 10000 \\
\hline 15. & Wielkopolskie & 61279 & 51279 & 4719 \\
\hline 16. & Zachodniopomorskie & 27887 & 23168 & 124418 \\
\hline Razem & 670461 & 546043 & \\
\hline
\end{tabular}

Źródło: (Rachubka 2015, s. 4).

W Polsce na jednego nauczyciela przypada około 9 uczniów. Spędza on ,przy tablicy" ponad $60 \%$ średniej czasu. Specjaliści przewidzieli co prawda zahamowanie niżu demograficznego, jednak nie ma mowy o wzroście liczby dzieci. Dodatkowo samorządy nie zwiększają swoich wydatków na szkolnictwo. Najgorzej sytuacja wygląda w małych gminach, gdzie do każdej złotówki otrzymanej z budżetu, trzeba dołożyć drugą z własnego. Dlatego gminy zmniejszają wydatki tam, gdzie jest to możliwe. Małe szkoły na wsiach są likwidowane, a nauczyciele tracą pracę i muszą poszerzać swoje kwalifikacje (Piotrowiak 2010).

Nauczyciele finansują z własnej kieszeni kolejne studia podyplomowe, które są szansą na zdobycie kilku dodatkowych godzin albo na utrzymanie pracy. $\mathrm{Na}$ jednym z blogów internetowych przeczytałam:

Zacząłem jako nauczyciel polskiego. Potem uczyłem jeszcze filozofii. Kilka lat później doszła etyka. Mamy już więc trzy przedmioty. W pewnym momencie filozofia wypadła. Zostały dwa. Rok temu w arkuszu organizacyjnym dopisano mi wiedzę o kulturze, ale ostatecznie przypadła innemu poloniście. Po odejściu na emeryturę łacinniczki istniało ryzyko, że ktoś z grona będzie musiał uczyć języka Cycerona. Problem jednak rozwiązał się sam - łaciny nie ma nawet w klasie humanistycznej. Gdyby jednak była, nie opłacałoby się ściągać specjalisty na dwie godziny. Wzięłaby je osoba, której trzeba skleić etat. Właściwie człowiek nawet nie wie, czego będzie uczył (Chętkowski 2016). 
Tab. 2. Poziom wykształcenia nauczycieli w roku szkolnym 2014/2015

\begin{tabular}{|l|c|c|c|c|c|c|}
\hline Województwo & $\begin{array}{c}\text { Liczba } \\
\text { nauczycieli } \\
\text { z tytułem } \\
\text { doktora } \\
\text { i doktora } \\
\text { habilitowanego }\end{array}$ & $\begin{array}{c}\text { Liczba } \\
\text { nauczy- } \\
\text { cieli } \\
\text { z wy- } \\
\text { kształce- } \\
\text { niem } \\
\text { wyższym }\end{array}$ & $\begin{array}{c}\text { Liczba } \\
\text { nauczycieli } \\
\text { z wykształ- } \\
\text { ceniem na } \\
\text { poziomie } \\
\text { KN i NKJO }\end{array}$ & $\begin{array}{c}\text { Liczba } \\
\text { nauczycieli } \\
\text { z wykształ- } \\
\text { ceniem na } \\
\text { poziomie } \\
\text { SN, PST } \\
\text { i SWP }\end{array}$ & $\begin{array}{c}\text { Liczba } \\
\text { nauczycie- } \\
\text { li z innym } \\
\text { wykształ- } \\
\text { ceniem }\end{array}$ & Razem \\
\hline Dolnó́ląskie & 397 & 45080 & 158 & 385 & 112 & 46335 \\
\hline $\begin{array}{l}\text { Kujawsko-po- } \\
\text { morskie }\end{array}$ & 294 & 35059 & 60 & 210 & 78 & 35853 \\
\hline Lubelskie & 323 & 39023 & 72 & 166 & 110 & 39907 \\
\hline Lubuskie & 75 & 16620 & 53 & 228 & 41 & 17095 \\
\hline Łódzkie & 365 & 40437 & 90 & 191 & 54 & 41304 \\
\hline Małopolskie & 557 & 59779 & 155 & 470 & 183 & 61536 \\
\hline Mazowieckie & 847 & 96537 & 332 & 529 & 222 & 99020 \\
\hline Opolskie & 132 & 16231 & 51 & 147 & 20 & 16639 \\
\hline Podkarpackie & 271 & 37840 & 101 & 257 & 101 & 38786 \\
\hline Podlaskie & 151 & 20522 & 66 & 140 & 55 & 21066 \\
\hline Pomorskie & 361 & 40452 & 86 & 202 & 97 & 41373 \\
\hline Śląskie & 741 & 73790 & 257 & 508 & 164 & 75852 \\
\hline Świętokrzyskie & 138 & 21090 & 43 & 73 & 59 & 21490 \\
\hline $\begin{array}{l}\text { Warmińsko- } \\
\text { mazurskie }\end{array}$ & 156 & 24545 & 60 & 120 & 48 & 25039 \\
\hline Wielkopolskie & 484 & 59774 & 153 & 500 & 107 & 61279 \\
\hline $\begin{array}{l}\text { Zachodniopo- } \\
\text { morskie }\end{array}$ & 208 & 27122 & 119 & 213 & 79 & 27887 \\
\hline Razem & 550 & 653901 & 1856 & 3335 & 1530 & 670461 \\
\hline
\end{tabular}

Źródło: (Rachubka 2015, s. 20).

W tych słowach zawarta jest współczesna rzeczywistość polskiego systemu kształcenia nauczycieli. Same nasuwają się pytania o jakość takiej edukacji. Czy nauczyciel, który uczy 3-4 przedmiotów, jest naprawdę specjalistą, a jeśli tak, to w którym? Czy posiadana przez niego i przekazywana uczniom wiedza jest rzetelna? Oczywiście nie można nie dostrzegać pozytywnych aspektów kilkuprzedmiotowej edukacji nauczycieli, do których znawcy problemu zaliczają m.in.: pogłębioną wiedzę specjalistyczną; interdyscyplinarność i przygotowanie specjalistów potrafiących łączyć w bloki treści przedmiotów humanistycznych; stworzenie podstaw do kontekstualnego czytania tekstów kultury, budowania holistycznych sytuacji dydaktycznych, traktowania ucznia jako podmiotu integrującego różne składniki wiedzy i umiejętności; ukształtowanie warunków dla wzbogacenia propozycji kół pozalekcyjnych; „wychowanie” nauczycieli otwartych na zmianę, świadomych potrzeb kształcenia ustawicznego i konieczności 
zdobywania nowych kwalifikacji; doprowadzenie do powstania nowej sytuacji w zakresie zatrudnienia, która możliwa jest dzięki temu, że jeden nauczyciel uczy kilku przedmiotów (Kulka 2008, s. 27).

\section{METODOLOGIA I CEL BADAŃ}

Celem przeprowadzonych badań było poznanie opinii nauczycieli z powiatu ostrowieckiego na temat jakości dokształcania z przedmiotów dodatkowych. Badania przeprowadzono wśród nauczycieli szkół podstawowych i gimnazjalnych powiatu ostrowieckiego. Grupa badawcza liczyła 173 osoby. Zastosowano metodę sondażu diagnostycznego, w ramach której wykorzystano technikę ankietowania. Kwestionariusz ankiety liczył 10 pytań dotyczących rodzaju wykształcenia, ilości ukończonych studiów podyplomowych oraz własnych spostrzeżeń dotyczących jakości uzyskanych kompetencji do nauczania dodatkowych przedmiotów. Uzyskane dane liczbowe poddano analizie ilościowej i jakościowej. Zastosowano także nieparametryczny test statystyczny $\mathrm{Chi}^{2}$.

Sformułowano następujące problemy badawcze:

I. Problem główny:

1. Jaką opinię prezentują nauczyciele szkół podstawowych i gimnazjalnych z powiatu ostrowieckiego na temat jakości kształcenia nauczycieli w zakresie dodatkowych przedmiotów?

II. Problemy szczegółowe:

1. Do nauczania ilu przedmiotów badani nauczyciele posiadają kwalifikacje?

2. W ilu szkołach pracują równocześnie badani nauczyciele, by mieć zapewniony etat?

3. Ile studiów podyplomowych ukończyli respondenci?

4. Czy badani nauczyciele uważają swoje kompetencje do nauki dodatkowych przedmiotów za wystarczające?

5. Czy staż pracy różnicuje poglądy nauczycieli dotyczące jakości kształcenia na studiach podyplomowych i poziomu własnych umiejętności merytorycznych uzyskanych $\mathrm{w}$ ich toku?

\section{WYNIKI BADAŃ}

Wśród nauczycieli uczestniczących w badaniu największa grupa $(34,1 \%)$ pracuje w zawodzie 5-10 lat, mają więc dość duże doświadczenie zawodowe. Nieco mniejszą grupę stanowią osoby wykonujące zawód nauczyciela 11-15 lat $(26,1 \%)$, natomiast najmniej liczną grupę tworzą nauczyciele z najdłuższym stażem - ponad 15 lat (17,9\%). Niemal 50\% respondentów pracuje w 3 placówkach, co powodowane jest oczywiście koniecznością „uzbierania” odpowiedniej liczby 
godzin. W 2 szkołach pracuje nieco ponad 25\% nauczycieli, a w 1 tylko 16,1\%. Wśród badanych znalazło się nawet kilka osób $(1,7 \%)$, które swój czas zawodowy zmuszone są dzielić aż między 4 placówki (rys. 1).

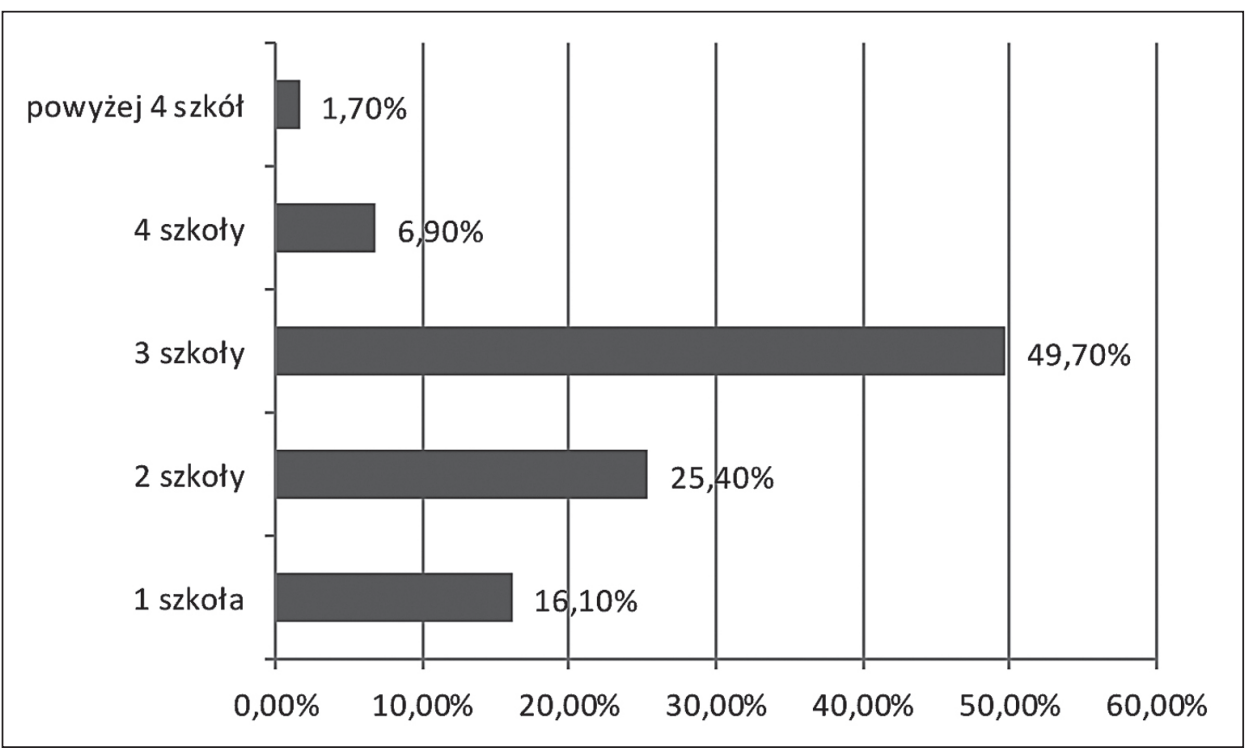

Rys. 1. Liczba placówek, w których badani nauczyciele prowadzą lekcje

Źródło: opracowanie własne.

Ponad połowa nauczycieli biorących udział w badaniu (56,1\%) pracuje równocześnie w szkołach miejskich i wiejskich (rys. 2). Jest to typowa sytuacja w powiecie ostrowieckim, gdzie nauczyciele, którzy uczą w szkołach (np. w Ostrowcu Świętokrzyskim), dojeżdżają również do okolicznych wiosek, by tam prowadzić lekcje. Znamienne jest też to, że zwykle cała kadra szkół wiejskich składa się z nauczycieli dojeżdżających każdego dnia na kilka lekcji.

Jedynie $2,8 \%$ badanych nauczycieli nie skończyło żadnych studiów podyplomowych uprawniających do nauczania drugiego przedmiotu. Oznacza to, że są to tzw. jednoprzedmiotowcy. Niemal 20\% nauczycieli skończyło jeden rodzaj studiów podyplomowych. Największą grupę stanowią natomiast osoby, które realizowały takie studia dwukrotnie (51,4\% całej grupy). Wśród respondentów znajdują się także nauczyciele posiadający ukończone aż trzy różne kierunki studiów podyplomowych $(16,7 \%)$. Niecałe $10 \%$ stanowią osoby, które więcej niż trzy razy podejmowały naukę na studiach podyplomowych (rys. 3).

Wśród badanych nauczycieli zdecydowanie przeważają wieloprzedmiotowcy. Ponad $45 \%$ z nich posiada uprawnienia do nauczania trzech różnych przedmiotów, a niewiele mniejsza grupa $(33,5 \%)$ może uczyć dwóch. Tylko nieco po- 


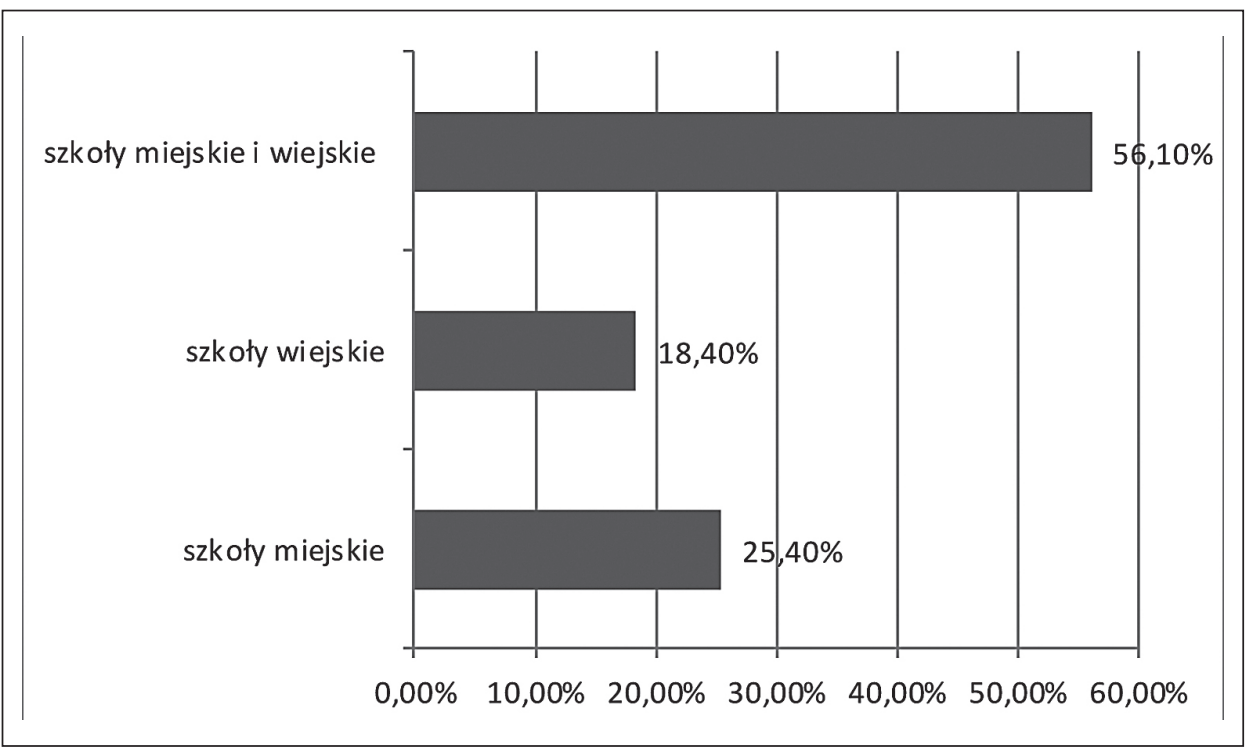

Rys. 2. Lokalizacja szkół, w których pracują badani nauczyciele

Źródło: opracowanie własne.

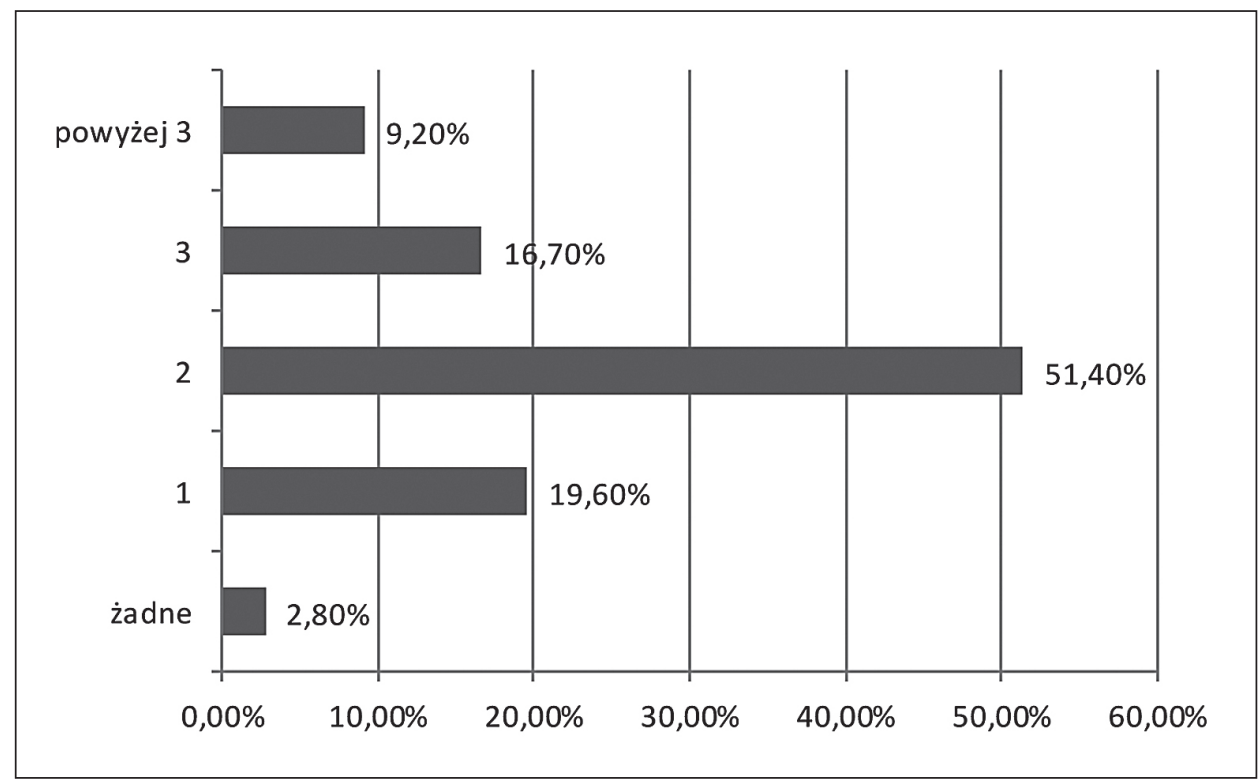

Rys. 3. Ilość studiów podyplomowych ukończonych przez respondentów Źródło: opracowanie własne. 


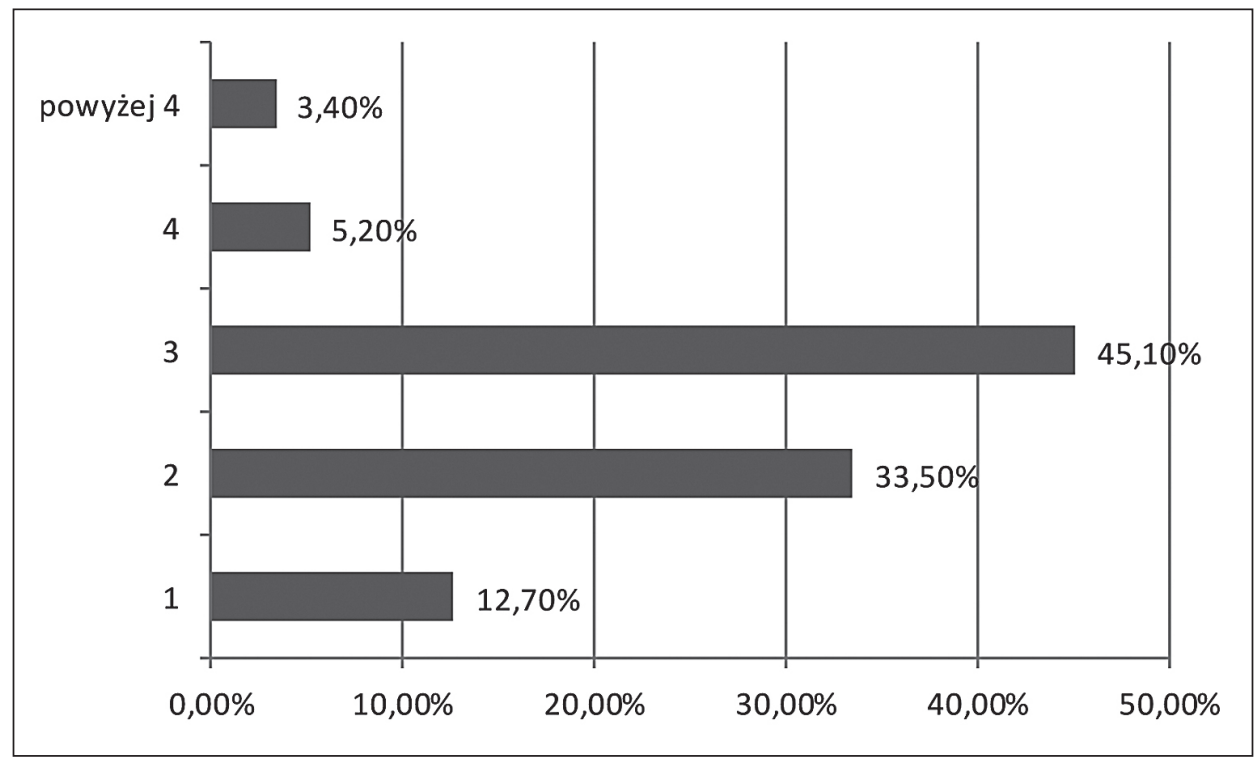

Rys. 4. Ilość przedmiotów nauczanych przez nauczycieli

Źródło: opracowanie własne.

wyżej $12 \%$ respondentów uczy jednego przedmiotu. Imponujący jest fakt, że w grupie badawczej znalazły się również osoby, które mogą nauczać czterech $(5,2 \%)$ i więcej $(3,4 \%)$ przedmiotów szkolnych (rys. 4$)$.

Najczęściej nauczyciele uczą dodatkowo przedmiotów, które są w mniejszym lub większym stopniu pokrewne z ich przedmiotem „macierzystym”. I tak matematycy prowadzą lekcje $\mathrm{z}$ informatyki, poloniści - z historii i wos-u, a plastycy - z techniki. Zdarza się tak, że geograf uczy chemii, wuefista - religii, a bio$\log$ - informatyki. Niepokoi fakt, że są poloniści, którzy najpierw uczyli w klasach I-III oraz angliści, których bazowym przedmiotem jest plastyka. Trudno bowiem wyobrazić sobie kompetentnego polonistę, który ukończył jedynie „weekendowe" studia podyplomowe.

Nauczyciele uczestniczący w badaniu oceniali jakość kształcenia na studiach podyplomowych, które ukończyli. Najliczniejszą grupę stanowią osoby, które określiły jakość jako średnią (29,4\%). Porównywalna jest liczba osób, które wskazały ocenę wysoką $(25,4 \%)$ oraz niską $(24,2 \%)$. Bardzo wysoko jakość ukończonych ,podyplomówek” oceniło $11,5 \%$, natomiast bardzo nisko $-8,6 \%$ i była to najmniej liczna grupa.

Z badań wynika, że niskie oceny jakości kształcenia częściej przyznawali nauczyciele z większym stażem pracy. Osoby, które pracują nie dłużej niż 10 lat były bardziej skłonne do oceniania jakości jako wysokiej lub bardzo wysokiej (rys. 5). W celu określenia, czy istnieje zależność istotna statystyczna między stażem pra- 


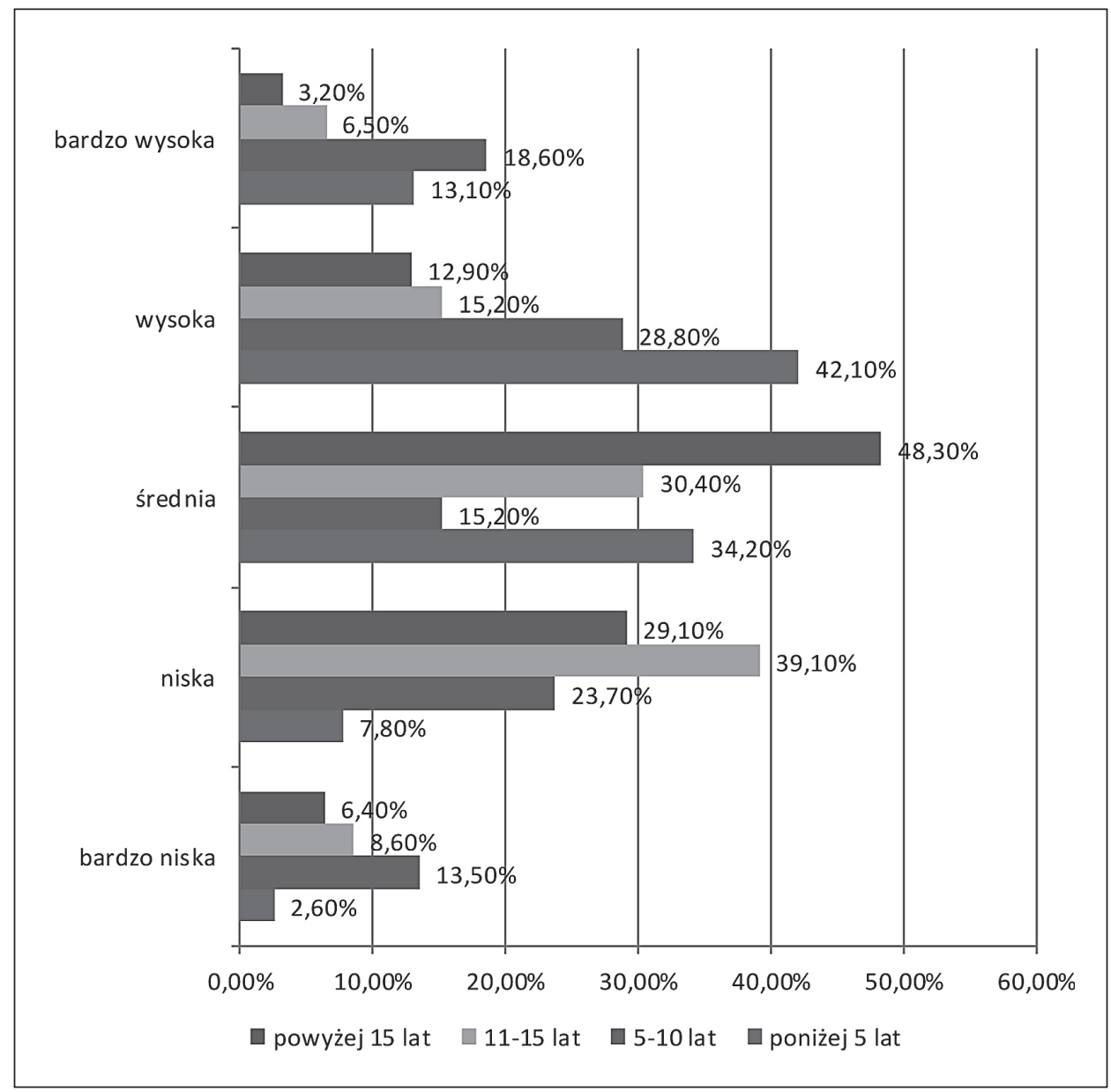

Rys. 5. Ocena jakości kształcenia na studiach podyplomowych przez badanych nauczycieli z uwzględnieniem ich stażu pracy

Źródło: opracowanie własne.

cy respondentów a dokonaną przez nich oceną jakości kształcenia na studiach podyplomowych, zastosowano nieparametryczny test statystyczny $\mathrm{Chi}^{2}$, który bada związki między zmiennymi jakościowymi (tab. 3). Wynik testu wskazuje na istnienie związku między tymi zmiennymi, którego siła jest przeciętna. Oznacza to, że inaczej jakość kształcenia oceniają nauczyciele z małym stażem, a inaczej ci, którzy wiele lat pracują w zawodzie.

Respondenci oceniali również jakość własnych umiejętności merytorycznych uzyskanych na studiach podyplomowych. W tym przypadku największą grupę stanowiły osoby przyznające jakość ,średnią” (45,1\%). Nisko własne umie- 
Tab. 3. Zależność między stażem pracy badanych nauczycieli a dokonaną przez nich oceną jakości kształcenia na studiach podyplomowych

\begin{tabular}{|l|c|c|c|}
\hline & Wartość & df & Istotność asymptotyczna (dwustronna) \\
\hline Chi ${ }^{2}$ Pearsona & 27,91 & 12 & 21,026 \\
\hline$x^{2}=27,91<x_{(0,05)=}^{2} 21,026$ & \\
\hline
\end{tabular}

Źródło: opracowanie własne.

jętności oceniło 21,9\%, a wysoką ocenę przyznało 17,9\% badanych. Poniżej 10\% stanowili nauczyciele oceniający własne umiejętności merytoryczne jako bardzo wysokie $(6,3 \%)$ oraz bardzo niskie $(8,6 \%)$.

Przyjęto hipotezę, iż staż pracy nauczycieli wpływa na ich ocenę własnych umiejętności merytorycznych uzyskanych na studiach podyplomowych. Analiza wyników pozwala stwierdzić, że im większy staż pracy, tym niższa jest ta ocena. Ponad połowa nauczycieli, którzy pracują w zawodzie więcej niż 15 lat, przyznała, że uzyskali na studiach podyplomowych umiejętności niskiej jakości, a 25,8\% dało im ocenę bardzo niską. Tylko $3,2 \%$ osób z tej grupy uznało własne umiejętności za wysokie. Do dawania wyższych ocen częściej skłonni byli nauczyciele, którzy pracują w zawodzie krócej niż 5 lat. 26,3\% z nich wyraziło opinię, że uzyskali w efekcie studiów podyplomowych umiejętności wysokiej jakości, a 10,5\% oceniło je jako bardzo wysokie (rys. 6).

Wynik testu $\mathrm{Chi}^{2}$ wskazuje na istnienie związku między stażem pracy badanych nauczycieli a dokonaną przez nich oceną jakości własnych umiejętności merytorycznych uzyskanych na studiach podyplomowych. Siła związku między tymi zmiennymi jest przeciętna.

Tab. 4. Zależność między stażem pracy badanych nauczycieli a dokonaną przez nich oceną jakości własnych umiejętności merytorycznych uzyskanych na studiach podyplomowych

\begin{tabular}{|l|c|c|c|}
\hline & Wartość & df & Istotność asymptotyczna (dwustronna) \\
\hline Chi $^{2}$ Pearsona & 40,98 & 12 & 21,026 \\
\hline$x^{2}=40,98<x_{(0,05)=}^{2} 21,026$ & \\
\hline
\end{tabular}

Źródło: opracowanie własne.

Z badań wynika, że różne są motywy podejmowania przez nauczycieli kształcenia $\mathrm{w}$ formie studiów podyplomowych. Większością kieruje chęć posiadania pełnego wymiaru godzin $(32,9 \%)$ oraz strach przed utratą pracy, jeśli nie zyskają dodatkowych kwalifikacji (28,3\%). Ponad $20 \%$ badanych przyznało, że o podjęciu tej formy dokształcania zadecydowała chęć pracy w jednej placówce. Wią- 


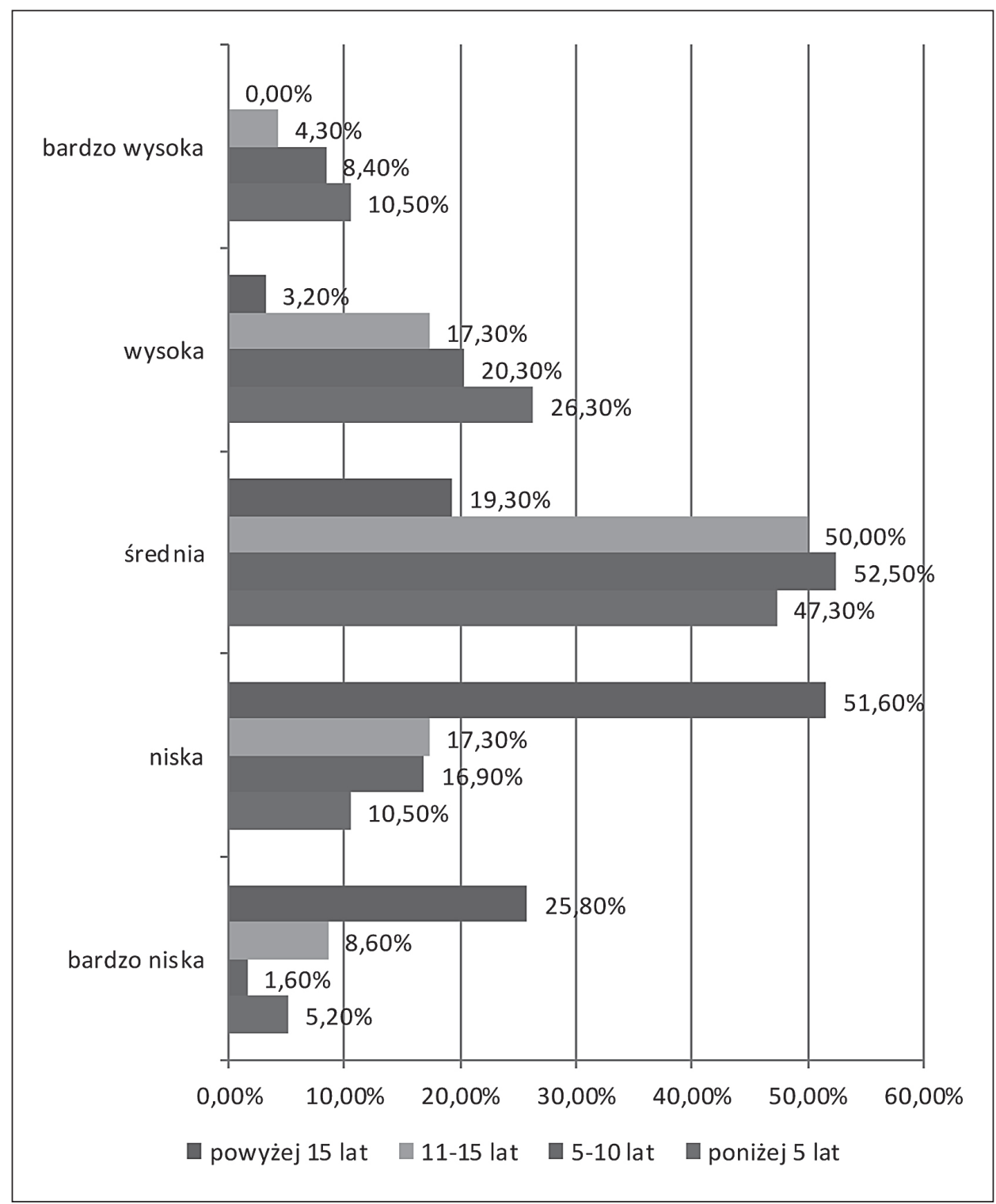

Rys. 6. Ocena własnych umiejętności merytorycznych zdobytych na studiach podyplomowych Źródło: opracowanie własne.

że się to z posiadaniem pełnego etatu - im szersze kwalifikacje, tym pewniejsze jest to, że nauczyciel znajdzie zatrudnienie w jednej szkole, ucząc kilku różnych przedmiotów. Niepokojące jest natomiast to, że tylko 5,7\% podejmowało studia z powodu chęci rozwoju zawodowego (rys. 7). 


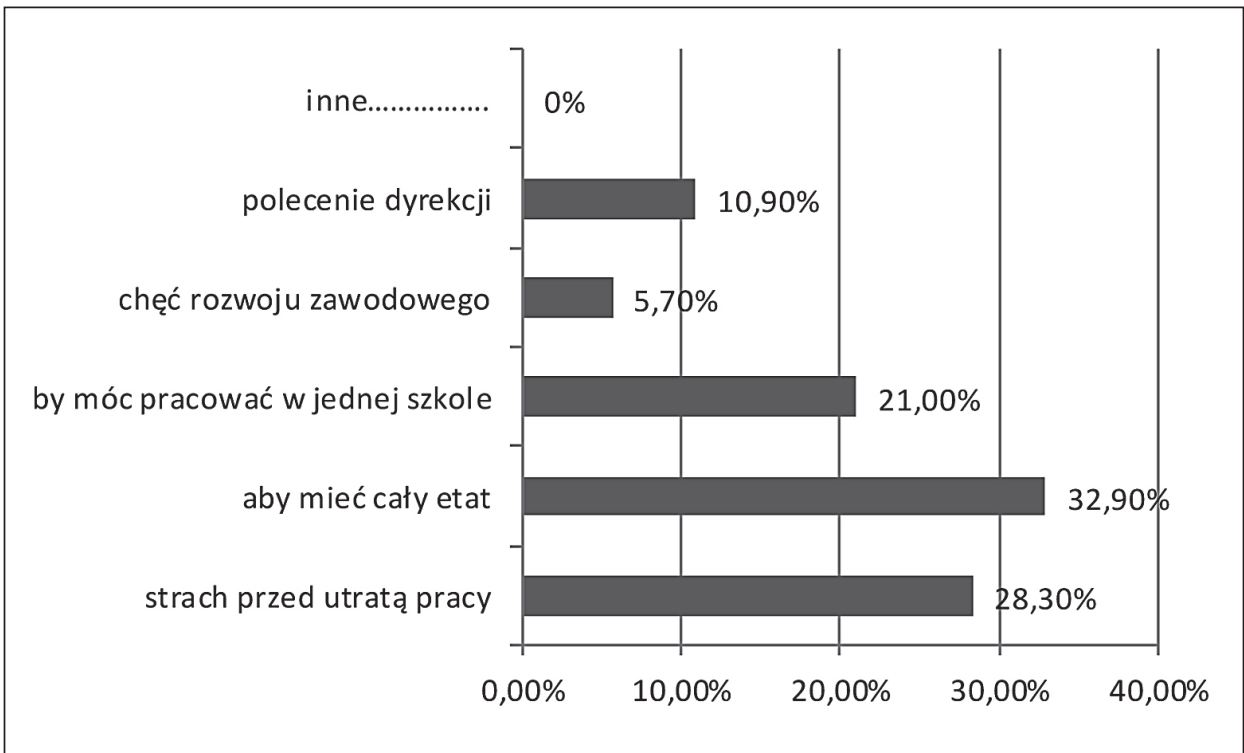

Rys. 7. Motywy podejmowania studiów podyplomowych przez badanych nauczycieli

Źródło: opracowanie własne.

\section{WNIOSKI}

Przeprowadzone badania pozwalają na sformułowanie następujących wniosków:

- zdecydowana większość nauczycieli posiada kwalifikacje do nauczania więcej niż jednego przedmiotu,

- badani nauczyciele najczęściej pracują w kilku placówkach równocześnie,

- respondenci w większości ukończyli przynajmniej jeden kierunek studiów podyplomowych uprawniających do nauczania drugiego przedmiotu,

- większość badanych ocenia swoje kompetencje do nauki dodatkowych przedmiotów jako średnie,

- między stażem pracy nauczycieli a dokonaną przez nich oceną jakości kształcenia na studiach podyplomowych i oceną poziomu własnych umiejętności merytorycznych uzyskanych w ich toku istnieje zależność istotna statystycznie.

$\mathrm{Z}$ uzyskanych w toku badań danych wynika, że uczestniczący w badaniu nauczyciele szkół podstawowych i gimnazjalnych z powiatu ostrowieckiego nie są do końca przekonani o wysokiej jakości kształcenia w zakresie dodatkowych przedmiotów. Dotyczy to zwłaszcza tych, którzy pracują w zawodzie długo i utoż- 
samiają jednoprzedmiotowość z solidną wiedzą w zakresie jednego przedmiotu. Dla młodych nauczycieli uczenie kilku, niekoniecznie powiązanych ze sobą, przedmiotów jest naturalnym stanem rzeczy. W dzisiejszej rzeczywistości edukacyjnej jest to konieczne, jeśli chce się pracować na całym etacie albo pracować w ogóle. Jakość uzyskanych w ten sposób kompetencji niestety zwykle pozostawia wiele do życzenia.

\section{BIBLIOGRAFIA}

Chętkowski D. (2016), Nauczyciele wielu przedmiotów, http://chetkowski.blog.polityka. pl/2016/08/08/nauczyciele-wielu-przedmiotow (dostęp: 10.05.2017).

Federowicz M., Sitek M. (red.) (2011), Spoleczeństwo w drodze do wiedzy. Raport o stanie edukacji 2010, Warszawa: Instytut Badań Edukacyjnych.

Kulka B. (2008), Kształcenie dwukierunkowe nauczycieli - możliwe skutki pozytywne i negatywne, [w:] K. Sujasz-Lesz (red.), Kształcenie nauczycieli w szkole wyższej. Wybrane zagadnienia, Wrocław: Oficyna Wydawnicza ATUT.

Kutrowska B. (2008), Spojrzenie na rolę nauczyciela z perspektywy różnych oczekiwań społecznych, [w:] P. Rudnicki, B. Kutrowska, M. Nowak-Dziemianowicz (red.), Nauczyciel: misja czy zawód? Społeczne i profesjonalne aspekty roli, Wrocław: Wydawnictwo Naukowe Dolnośląskiej Szkoły Wyższej.

Kuźma J. (2001), Nauczyciele przyszłej szkoły, [w:] K. Denek, T.M. Zimny (red.), Edukacja jutra. VI Tatrzańskie Seminarium Naukowe, Częstochowa: Agencja Promocji Nauki i Kultury MENOS s.c.

Piotrowiak K. (2010), Jeden nauczyciel - dwa dyplomy, www.dziennikzachodni.pl/ artykul/213496,jeden-nauczyciel-dwa-dyplomy,3,id,t,sa.html (dostęp: 10.05.2017).

Podoska-Filipowicz E., Kwalifikacje wspótczesnych nauczycieli i ich rola $w$ procesie edukacji, https://zasobyip2.ore.edu.pl/pl/publications/download/9410 (dostęp: 10.05.2017).

Pruch J. (2006), Pedeutologia, [w:] B. Śliwerski (red.), Pedagogika, t. 2, Gdańsk: Gdańskie Wydawnictwo Pedagogiczne.

Rachubka M. (2015), Nauczyciele w roku szkolnym 2014/2015, Warszawa: ORE.

Rutkowiak J. (1995), Edukacyjna świadomość nauczycieli: intelektualizacja pracy nauczycielskiej jako wyzwanie czasu transmisji, [w:] Odmiany myślenia o edukacji, Kraków: Impuls.

\section{SUMMARY}

Nowadays it is increasingly difficult to find a teacher who is only qualified to teach one subject. Teachers are faced with very high demands, which are often difficult to meet. This has contributed greatly to the state of affairs of the civilization revolution, the huge increase in information and the unprecedented pace of change that has strengthened the value of education in the labor market and has made its quality one of the priorities of modern education. More and more often we are dealing with multi-faceted teachers, which means that one teacher has the competence to teach two or more subjects. Often these extra items are quite distant from this basic.

This situation is largely dictated by economic considerations. The school prefers to have fewer omni-directional teachers who do the work of a dozen or so people, which greatly reduces the cost of employment. It is also beneficial from the perspective of the teachers themselves, who find it 
increasingly difficult to keep up in school. Acquiring qualifications in areas that do not coincide in any way is currently a common phenomenon in the Polish education system.

The aim of the research was to get acquainted with the opinions of teachers from the Ostrowiec district on the quality of supplementary education. The research was conducted among teachers of primary and lower secondary schools in the Ostrowiec district. The diagnostic survey method was applied, which used the polling technique.

Keywords: multidirectionality; quality of education; postgraduate studies 